\title{
JIE
}

JOURNAL OF ISLAMIC EDUCATION

Vol. 7 No. I Mei 2022

P-ISSN 2503-5363; E-ISSN 2528-0465

http://www.ejournal.stitmuhbangil.ac.id/index.php/jie

\section{Strategi Guru Menumbuhkan Minat Belajar Pendidikan Agama Islam Bagi Siswa Difabel}

\author{
Azhar Rahmanto \\ (Universitas Islam Negeri (UIN) Sunan Kalijaga, Jl. Laksda Adisucipto, DIY, Indonesia) \\ *azharrahmanto01@gmail.com
}

\begin{tabular}{l}
\hline Informasi Artikel \\
\hline Received: \\
9 October 2021
\end{tabular}

Accepted:

10 November 2021

\section{Published:}

2 May 2022

\section{Keywords:}

Interest in Learning,

Mental Retardation,

Islamic Religious

Education.

\begin{abstract}
The background of this research is, learning strategy is one of the most important factors in a learning process. With the disorder that is owned, a strategy is needed that is in accordance with the conditions and abilities of the mentally retarded students. This study aims to determine the learning strategies of PAI teachers in fostering interest in learning for students with disabilities. The purpose of this study was to find out what strategies have been used by PAI teachers in growing interest in learning Islamic Religious Education at SLB E Prayuana. This research is a descriptive qualitative research based on field research. Data collection methods used in this study are observation methods, interview methods, and documentation. Data analysis used in this research is descriptive analytical method. The results of this study indicate that the learning interest of mentally retarded students at SLB E Prayuwana Yogyakarta is quite low. However, sometimes students can appear interested in the lesson if the factors that influence student interest are in good condition, such as students not having problems before entering school or entering class, students feel comfortable being with the teacher in the classroom, a supportive environment (nothing is distracting), students have experience about the material being taught, students are curious about what the teacher is teaching. The strategy used by the teacher to foster interest in learning for mentally retarded
\end{abstract}


students at SLB E Prayuwana Yogyakarta is to apply the CTL and PAIKEM strategies.

Latar belakang penelitian ini adalah, strategi pembelajaran merupakan salah satu faktor terpenting dalam sebuah proses pembelajaran. Dengan kelainan yang dimiliki, diperlukan strategi yang sesuai dengan kondisi dan kemampuan siswa tunagrahita. Penelitian ini bertujuan untuk mengetahui strategi pembelajaran guru PAI dalam menumbuhkan minat belajar pada siswa difabel. Tujuan penelitian ini adalah untuk mengetahui strategi apa yang telah digunakan guru PAI dalam menumbuhkan minat belajar Pendidikan Agama Islam di SLB E Prayuana. Penelitian ini merupakan penelitian kualitatif deskriptif berdasarkan penelitian lapangan. Metode pengumpulan data yang digunakan dalam penelitian ini adalah metode observasi, metode wawancara, dan dokumentasi. Analisis data yang digunakan dalam penelitian ini adalah metode deskriptif analitis. Hasil penelitian ini menunjukkan bahwa minat belajar siswa tunagrahita di SLB E Prayuwana Yogyakarta cukup rendah. Namun terkadang siswa dapat terlihat tertarik dengan pelajaran jika faktor-faktor yang mempengaruhi minat siswa dalam kondisi baik, seperti siswa tidak mengalami masalah sebelum masuk sekolah atau memasuki kelas, siswa merasa nyaman berada bersama guru di dalam kelas, lingkungan yang mendukung. tidak ada yang mengganggu), siswa memiliki pengalaman tentang materi yang diajarkan, siswa penasaran dengan apa yang diajarkan guru. Strategi yang digunakan guru untuk menumbuhkan minat belajar siswa tunagrahita di SLB E Prayuwana Yogyakarta adalah dengan menerapkan strategi CTL dan PAIKEM.

\section{PENDAhUluan}

Minat dalam diri siswa sangat penting dalam proses pembelajaran. Apabila siswa berminat dengan apa yang sedang dipelajari maka siswa akan memperhatikan pelajaran yang sedang diajarkan oleh guru sehingga materi pelajaran akan lebih mudah difahami dan diingat oleh murid. Maka sebaliknya, 
jika minat belajar siswa rendah maka siswa akan tidak terlalu memperhatikan apa yang sedang diajarkan oleh guru saat proses pembelajaran, sehingga materi yang diajarkan sulit untuk difahami dan dimengerti oleh siswa. Hal tersebut sesuai dengan penelitian yang pernah dilakukan oleh Rusmiati yang menyatakan bahwa minat dalam proses belajar mengajar merupakan salah satu faktor yang besar pengaruhnya terhadap prestasi belajar (Rusmiati, 2017). Siswa yang minat belajarnya tinggi akan memperoleh prestasi belajar baik.

Menurut Khairani, siswa menjadi kurang minat dalam belajar karena siswa merasa materi pelajaran yang disampaikan kurang menarik, belum menyadari pentingnya ilmu yang sedang dipelajari untuk masa depan serta adanya gangguan fisik atau kesehatan yang menghambat (Khairani, 2017). Apabila guru sudah merasa bahwa murid kurang berminat dalam pelajaran yag diajarkan, maka sebaiknya guru dapat menyusun strategi pembelajaran yang tepat. Strategi tersebut dapat berupa melakukan pelajaran dengan menggunakan variasi dalam penyampaian materi, menggunakan media pembelajaran yang lebih interaktif, dan lain sebagainya, sehingga dapat menumbuhkan minat belajar siswa.

Kurangnya minat belajar tidak hanya dirasakan oleh siswa yang berbada sehat, namun juga bias dirasakan oleh siswa dengan kebutuhan khusus atau yang lebih dikenal dengan difabel. Bagi siswa difabel, dengan keterbatasan yang dimiliki membuat siswa kurang berminat dalam mempelajari beberapa hal atau pelajaran karena berbagai alasan, ada yang karena metode yang digunakan dalam pelajaran kurang menarik, ada yang karena mengaggap pelajaran tersebut terlalu sulit untuk difahami dan berbagai alasan lainnya yang membuat siswa kurang berminat (Maftuhin \& Fuad, 2018). Selain faktor tersebut, terdapat 3 faktor lainnya yang dapat mempengaruhi minat belajar siswa yaitu faktor internal seperti kondisi jasmani dan rohani siswa, faktor eksternal seperti kondisi lingkungan sekitar serta faktor pendekatan yakni jenis upaya belajar siswa seperti strategi dan metode yang digunakan dalam pembelajaran pembelajaran (Rahmanto, 2017).

Berdasarkan hasil studi pendahuluan di SLB E Prayuwana Yogyakarta ditemukan bahwa minat belajar anak tunalaras di sekolah tersebut masih sangat rendah. Jika di lihat dari faktor internal, hal ini disebabkan kelainan emosi dan 
perilaku yang dimiliki oleh anak tunalaras, hal ini juga menjadi penyebab kemampuan anak yang rendah untuk mengingat dan memahami sesuatu yang diajarkan karena sulit untuk konsentrasi. Selain itu juga permasalahan yang terbawa ke dalam kelas juga menjadi faktor penghambat siswa untuk bisa berminat terhadap apa yang sedang di pelajarinya.

Sedangkan jika di lihat dari faktor eksternal, kurangnya minat belajar siswa saat pelajaran PAI dapat disebabkan setting lingkungan sekolah dan kelas yang kurang berwarna dan kurang terawat menjadi salah satu penyebab rendahnya minat belajar siswa khususnya untuk pelajaran PAI karena siswa merasa kurang nyaman. Pelaksanaan pembelajaran yang menyatukan siswa dari beberapa kelas dalam satu jam pelajaran juga menjadi salah satu faktor penghambat tumbuhnya minat belajar PAI. Selain itu juga ditemukan bahwa guru PAI di SLB E Prayuwana Yogyakarta adalah lulusan fakultas syariah UIN Sunan Kalijaga Yogyakarta bukan lulusan dari fakultas pendidikan, dan juga belum pernah mengikuti pelatihan khusus PLB, maupun program sertifikasi guru, karena beliau pekerjaan utamanya adalah sebagai penyuluh agama di KUA.

Berdasarkan hasil observasi terkait faktor pendekatan, diketahui bahwa pendekatan startegi pembelajaran yang kurang sesuai dengan kondisi dan kebutuhan siswa dan metode pembelajaran yang cenderung monoton sehingga siswa terkadang merasa bosan, walaupun terkadang guru juga menggunakan metode-metode yang diharapkan dapat menarik dan menumbuhkan minat belajar siswa, dan juga siswa tidak mengetahui apa tujuan dari materi yang diajarkan. Siswa masih sering terlihat tidak memperhatikan apa yang guru ajarkan, terkadang siswa merasa bosan dengan materi yang diajarkan, siswa juga mudah lupa dengan apa yang sudah diajarkan oleh guru, dan saat siswa sudah merasa bosan maka guru tidak dapat memaksa siswa untuk terus mengikuti proses pembelajaran sehingga terkadang pelajaran PAI kosong walaupun murid dan guru ada.

Guna mengatasi hal tersebut, sudah seharusnya seorang guru memiliki kualifikasi dan kompetensi yang memumpuni untuk menyusun strategi pembelajaran yang tepat agar dapat menumbuhkan minat belajar siswa, agar 
siswa dapat memiliki keinginan untuk mempelajari mata pelajaran yang ingin diajarkan oleh guru. Seorang guru seharunya menyadari pentingnya peranan strategi dalam suatu proses pembelajaran (Ikhwan, 2019). Guru perlu menemukan cara yang tepat dalam mengajarkan pendidikan agama islam pada anak difabel khususnya difabel tunalaras.

Bagi siswa tunalaras, diperlukan pendekatan teoris sebagai tolak ukur kondisi siswa tunalaras. Hal ini sudah mencakup teknik dan strategi yang dilakukan guru dalam menghadapi siswa, baik di luar maupun di dalam kelas yaitu pendekatan Biomedis, pendekatan Psikodinamik, pendekatan Perilaku, pendekatan Pendidikan, pendekatan Ekologi (Oktari, Harmi, \& Wanto, 2020). Ketika menyusun strategi yang tepat guru dapat menganalisa bagaimana karakteristik siswa hal apa saja yang dibutuhkan dalam mengajar, dan pendekatan yang paling tepat untuk digunakan. Sehingga proses belajar mengajar dapat berjalan efektif dan efisien sesuai seperti yang diinginkan dan tujuan yang diharapkan dapat tercapai dengan optimal. Strategi guru adalah pendekatan umum mengajar yang berlaku dalam berbagai bidang materi dan digunakan untuk memenuhi berbagai tujuan pembelajaran (Enggan \& Kauchak, 2012).

Berdasarkan hal tersebut, maka perlu adanya penelitiana terkait strategi guru dalam menumbuhkan minat belajar siswa khususnya dalam pelajaran Pendidikan Agama Islam bagi siswa difabel tunalaras. Penelitian terkait strategi guru dalam menumbuhkan minat belajar siswa khususnya dalam pelajaran Pendidikan Agama Islam bagi siswa difabel tunalaras masih jarang ditemui. Salah satu penelitian terdahulu yang selaras dengan penelitian ini adalah penelitian yang pernah dilakukan oleh Mahfida yang berfokus pada faktor pendukung, penghambat dan pelaksanaan pembelajaran PAI di SLB E Prayuwana Yogyakarta (Mahfida, 2017). Kemudian penelitian Anwar yang fokus pada pembahasan tentang metode pembelajaran PAI pada anak tunalaras di SLB Bhina Putra Surakarta (A. W. Anwar, 2018). Terkait dengan metode penanaman nilai-nilai religius terhadap siswa difabel tunalaras jurnal ilmiah dari Husna berjudul Internalisasi Nilai-Nilai Sosial Religius Bagi Anak Tunalaras di SLB E Prayuwana Yogyakarta yang memberikan kesimpulan bahwa untuk proses penanaman nilai- 
nilai religius untuk siswa difabel tunalaras dibutuhkan metode-metode yang khusus (Husna, 2020). Selain itu juga terdapat karya jurnal ilmiah oleh Setiawan yang berfokus pada motivasi belajar siswa tunalaras (Setiawan, 2009). Penelitian yang pernah dilakukan Amidah yang membahas tentang minat belajar siswa pada mata pelajaran Pendidikan Agama Islam dan strategi guru dalam proses pembelajaran untuk peningkatan minat belajar siswa pada mata pelajaran Pendidikan Agama Islam di SDN 147 Palembang menghasilkan fakta bahwa untuk membangkitkan minat belajar siswa pada mata pelajaran PAI, guru melakukan strategi yaitu dengan memberikan perhatian dan insentif (Amidah, 2014). Hal tersebut cukup efektif dalam meningkatkan minat belajar siswa. Berdasarkan latar belakang tersebut, peneliti tertarik untuk melakukan penelitian lebih lanjut terkait strategi guru menumbuhkan minat belajar Pendidikan Agama Islam bagi siswa difabel tunalaras di SLB Prayuana.

\section{METODE PENELITIAN}

Penelitian ini merupakan penelitian lapangan (field research) yang bersifat kualitatif deskriptif dengan tujuan untuk menggambarkan dan mengungkap, dan menjelaskan tentang Strategi Pembelajaran Guru PAI Menumbuhkan Minat Belajar Bagi Siswa Difabel Tunalaras di SLB E Prayuwana Yogyakarta. Subyek penelitian dipilih dengan cara accessible population atau populasi yang tersedia yaitu kepala sekolah, seorang guru PAI, dan tiga siswa tunalaras. Data yang akan diperoleh dari kepala sekolah antara lain: letak geografis sekolah, sejarah berdirinya sekolah, dan visi misi sekolah. Adapun data yang akan diperoleh dari guru PAI antara lain: strategi yang digunakan untuk menumbuhkan minat belajar agama islam pada siswa PAI, faktor pendukung dan penghambat dalam pelaksanaan strategi tersebut. Sedangkan data yang akan diperoleh dari siswa adalah minat siswa terhadap pelajaran agama islam. Pengumpulan data pada penelitian ini didapatkan dengan menggunakan metode observasi, wawancara dan dokumentasi. Analisis data yang digunakan adalah analisis deskriptif kualitatif dalam bentuk laporan atau uraian deskripsi dengan melaporkan atau menjelaskan kejadian atau keadaan yang sebenarnya, mengklarifikasi dan dituangkan dalam 
bentuk kata-kata sehingga akhirnya dapat ditarik suatu kesimpulan (Ikhwan, 2021).

\section{TEMUAN DAN PEMBAHASAN}

\section{Minat Belajar SiswaTunalaras di SLB E Prayuwana Yogyakarta}

Berdasarkan hasil penelitian yang ada pada siswa tunalaras di SLB E Prayuwana Yogyakarta menunjukan bahwa karakteristik minat belajar khususnya pada pelajaran PAI cukup rendah. Hal tersebut dapat diketahui ketika saat proses pembelajaran siswa masih sering terlihat tidak memperhatikan apa yang guru ajarkan, terkadang siswa merasa bosan dengan materi yang diajarkan, terkadang main handphone dikelas, siswa terkadang menjawab asal-asalan pertanyaan yang diberikan oleh guru, siswa juga mudah lupa dengan apa yang sudah diajarkan oleh guru, dan saat siswa sudah merasa bosan maka guru tidak dapat memaksa siswa untuk terus mengikuti proses pembelajaran karena jika dipeksa maka siswa dapat melawan sehingga terkadang pelajaran PAI kosong walaupun murid dan guru ada.

Namun, tidak setiap waktu siswa tidak berminat terhadap pelajaran, menurut hasil wawancara dan observasi selama penelitian, siswa dapat terlihat berminat dengan pelajaran yang diajarkan jika faktor-faktor yang mempengaruhi minat siswa dalam kondisi yang baik, seperti siswa tidak memiliki masalah sebelum masuk sekolah atau masuk pelajaran, siswa merasa nyaman berada bersama guru di dalam kelas, lingkungan yang mendukung (tidak ada yang mengganggu), siswa mempunyai pengalaman tentang materi yang diajarkan, siswa ingin tahu tentang apa yang sedang diajarkan oleh guru. Sehingga dapat diketahui bahwa tumbuhnya minat belajar pada siswa SLB E Prayuwana Yogyakarta tergantung pada faktor-faktor yang mempengaruhinya.

Menurut Syah terdapat beberapa faktor yang dapat mempengaruhi minat belajar siswa antara lain faktor internal dan faktor eksternal (Syah, 2011). Dan faktor pendekatan Faktor internal meliputi kondisi jasmani dan rohani siswa. Berdasarkan hasil penelitian, siswa di SLB E Prayuwana memiliki keingingan atau cita-cita untuk bisa mendapatkan nilai yang baik agar bisa naik kelas atau bisa lulus dari sekolah. Hal ini penting sehingga dapat menumbuhkan minat belajar 
siswa. Selain itu, kemampuan siswa juga menjadi salah satu faktor internal yang mempengaruhi minat belajar siswa. Siswa SLB E Prayuwana memiliki kemampuan yang cukup kurang untuk dapat memahami dan mengingat apa yang telah dipelajari dan diajarkan oleh guru. Berdasar hasil wawancara rendahnya kemampuan siswa untuk menangkap apa yang sudah dipelajari, dikarenakan adanya gangguan emosi dan perilaku yang ada pada siswa, sehingga siswa kurang bisa konsentrasi dalam belajar yang kemudian mempengaruhi kemampuan siswa. Akan tetapi berdasarkan hasil wawancara terhadap guru di SLB E Prayuwana, siswa masih mampu untuk belajar beberapa materi pembelajaran yang tidak terlalu sulit seperti membaca, menulis, baca Iqra'.

Apabila dilihat dari kondisi siswa, rata-rata siswa di SLB E Prayuwana memiliki kondisi fisik yang sehat serta tidak memiliki cacat pada tubuh, akan tetapi Untuk kondisi rohani siswa bisa dikatakan kurang. Hal ini bisa dilihat dari perilaku siswa yang terkadang masih menyimpang yang disebabkan gangguan tunalaras yang ada. Siswa di SLB E Prayuwana Yogyakarta memiliki gangguan pada perilaku dan emosi yang mengganggu psikologis siswa baik dari segi minat, intelegensi, perhatian, kematangan dan kesiapan. Berdasarkan hasil observasi terlihat bahwa beberapa siswa mengalami kelelahan jasmani dengan ciri-ciri yang sudah disebutkan, hal ini bisa disebabkan karena siswa merasa kelelahan setelah bermain saat jam istirahat, sehingga ketika masuk pelajaran setelah jam istirahat siswa merasa kelelahan. Selain kelelahan jasmani, siswa SLB E Prayuwana juga merasakan kelelahan rohani, hal tersebut dapat terlihat ketika siswa sudah terlihat tidak tertarik dengan materi yang diajarkan sehingga minat siswa untuk belajar menurun.

Faktor selanjutnya yang mempengaruhi minat belajar siswa di SLB E prayuwana adalah faktor eksternal. Faktor eksternal terdiir dari kondisi lingkungan siswa, Unsur-unsur dinamis dalam belajar dan pembelajaran serta Upaya guru dalam membelajarkan siswa. Berdasar hasil wawancara dengan guru PAI, ketika ada teman yang tidak ingin belajar, kemudian bermain diluar kelas, bahkan mengganggu teman-teman yang lain yang sedang belajar, hal ini membuat siswa yang sedang belajar dapat terpecah konsentrasinya ketika belajar sehingga ketiga 
guru sudah berusaha untuk membuat siswa berminat dengan pelajaran yang diajarkan seketika usaha tersebut sia-sia ketika ada temannya yang mengganggu dan mempengaruhi minat belajar siswa tersebut. Kemudian kondisi kelas yang kurang berwana dan menarik terdapat pula kelas yang kurang sirkulasi udaranya. Berdasar hasil observasi yang telah dilakukan, kondisi lingkungan sekolah yang kurang berwarna dan kurang menarik menjadi salah satu penyebab rendahnya minat belajar siswa.

Selain lingkungan kelas, lingkungan keluarga juga berpengaruh terhadap minat belajar siswa, keluarga yang bermasalah, atau tidak adanya perhatian dari keluarga siswa untuk memotivasi, mempengaruhi tumbuhnya minat belajar siswa. lingkungan di tempat tinggal siswa juga berpengaruh terhadap tumbuhnya minat belajar siswa. Siswa yang di rumah bergaul dengan teman-teman yang tidak baik, dapat mempengaruhi sikap dan perilaku siswa dalam proses pembelajaran di sekolah (S. Anwar, 2021).

Menurut hasil penelitian di SLB E Prayuwana terdapat unsur-unsur dinamis yang dapat mempengaruhi minat belajar siswa, seperti perasaan siswa saat akan memulai belajar di sekolah atau dikelas, terkadang sebelum masuk sekolah dapat saja siswa mempunyai masalah yang dibawa dari rumah atau saat sebelum masuk kelas siswa memiliki suatu masalah pada sesama temannya atau pada gurunya yang menybabkan timbul emosi yang tidak baik yang tidak terkendali dalam diri siswa yang kemudian berpengaruh pada tumbuhnya minat siswa untuk mengikuti pelajaran di kelas.

Upaya guru dalam proses belajar mengajar juga sangat penting. upaya yang berpengaruh pada tumbuhnya minat belajar pada siswa yaitu dengan menggunakan strategi pembelajaran yang sudah disesuaikan dengan kondisi dan kemampuan anak. Namun, berdasar hasil observasi dan wawancara yang peneliti lakukan, metode yang digunakan dalam proses pembelajaran masih kurang menyenangkan atau cenderung itu-itu saja, yang terkdang membuat siswa merasa bosan saat proses pembelajaran, yang kemudian mempengaruhi minat siswa untuk belajar. Sehingga untuk menumbuhkan minat belajar siswa diperlukan adanya strategi pembelajaran dari guru PAI yang lebih kreatif dan inovatif agar 
dapat menumbuhkan minat belajar pada siswa, karena strategi pembelajaran merupakan salah satu faktor penting yang dapat mempengaruhi minat belajar siswa. Kemudian jam pelajaran yang dijadikan satu dengan kelas-kelas lain menyebabkan dalam satu kelas terdapat beragam karakteristik dan kemampuan siswa, seperti contohnya dalam satu jam pelajaran ada siswa dengan berbagai macam gangguan, seperti tunalaras murni jadi satu dengan yang campuran tunalaras dan tunagrahita, dan juga jadi satu dengan yang tunagrahita murni. Sehingga guru terkadang kewalahan dengan karakteristik siswa yang berbedabeda dalam satu kelas.

\section{Implementasi Strategi Pembelajaran untuk Menumbuhkan Minat Belajar Siswa Tunalaras di SLB E Prayuwana Yogyakarta}

Strategi pembelajaran merupakan suatu rencana untuk suatu kegiatan pembelajaran yang didalamnya meliputi metode dan perangkat kegiatan yang direncanakan untuk mencapai tujuan pengajaran tertentu. Pemilihan strategi pembelajaran yang sesuai dengan materi, kondisi, keadaan, dan kemampuan siswa akan membuat proses pembelajaran lebih optimal. Strategi pembelajaran sangat berpengaruh dalam menumbuhkan minat belajar siswa tunalaras di SLB E Prayuwana Yogyakarta. Berikut merupakan beberapa implementasi startegi pembelajaran yang telah dilakukan oleh guru di SLB E Prayuwana Yogyakarta:

1. Membuat siswa merasa nyaman di sekolah dan kelas

Strategi pembelajaran yang digunakan di SLB E Prayuwana Yogyakarta disesuaikan dengan kondisi dan kemampuan siswa. Terdapat beberapa usaha yang dilakukan pihak sekolah maupun guru dalam pelaksanaan strategi pembelajaran. Jika dilihat dari hasil wawancara dengan guru PAI, strategi yang digunakan oleh guru PAI agar dapat tumbuh minat belajar pada siswa tunalaras di SLB E Prayuwana Yogyakarta adalah pertama dengan berusaha membuat siswa bisa merasa senyaman mungkin dengan guru. Diharapkan setelah murid merasa nyaman dengan guru, sehingga guru dapat melaksanakan strategi pembelajaran untuk menumbuhkan minat belajar siswa.

Cara yang digunakan guru PAI untuk membuat siswa nyaman yaitu dengan berusaha berkomunikasi dengan cara sebaik mungkin dengan bahasa yang halus 
dan sopan agar siswa dapat merasa nyaman dengan sikap guru yang baik dan sopan terhadap siswa, walaupun terkadang siswa menanggapi hal tersebut tidak sesuai dengan yang diharapkan oleh guru atau tidak sebaik yang telah guru lakukan pada siswa, guru tetap harus bersabar dan mengikuti situasi dan kondisi siswa. Ketika siswa sudah merasa nyaman dan mau untuk mengikuti pelajaran atau tidak ada masalah saat proses pembelajaran, strategi pembelajaran yang digunakan oleh guru lebih kepada penggunaan strategi pembelajaran langsung, yaitu strategi yang bersifat deduktif yang banyak diarahkan oleh guru atau teacher centered learning. Namun guru tetap berusaha menggabungkan dengan strategi PAIKEM (Pembelajaran yang Aktif, Inovatif, Kreatif, dan Menyenangkan) dan CTL (Contextual Learning) yang sesuai dengan salah satu tujuan sekolah.

2. Penggunaan strategi pembelajaran PAIKEM dan CTL

Berdasarkan hasil observasi dan wawancara diketahui bahwa seluruh guru di SLB E Prayuwana Yogyakarta telah melaksanakn pembelajaran dengan pendekatan PAIKEM dan CTL. Dalam strategi CTL suumber pengetahuan adalah berasal dari luar diri siswa, yang kemudian diarahkan pada upaya membangun kemampuan berfikir dan kemampuan menguasai materi pembelajaran. Sehingga dalam strategi ini pengetahuan diperoleh berdasarkan hasil upaya dan konstruksi pemikiran siswa. Ketika menerapan strategi pembelajaran PAIKEM dan CTL, guru berusaha secara aktif berinteraksi dengan murid. Guru menerapkan metodemetode pembelajaran yang sudah disesuaikan dengan kemampuan dan kebutuhan murid agar siswa dapat aktif dan merasa senang dalam mengikuti proses pembelajaran sehingga diharapkan dapat tumbuh minat belajar pada siswa.

Dalam pelaksanaan strategi pembelajaran untuk menumbuhkan minat belajar siswa, strategi PAIKEM yang terlihat saat pelajaran adalah guru berusaha menggunakan media seperti laptop atau telepon genggam yang dimiliki guru untuk menampilkan video atau gambar yang berkaitan dengan materi, kemudian terkadang guru mengajak siswa belajar di luar ruang kelas seperti di masjid atau tempat-tempat lain yang berkaitan dengan materi pembelajaran untuk menumbuhkan minat belajar siswa. 
Kemudian guru PAI juga menerapkan strategi pembelajaran CTL yang juga bertujuan untuk menumbuhkan minat belajar siswa, yaitu dengan adanya sesi membaca sambil diskusi tulisan yang sudah ditulis oleh guru dan siswa. Dalam sesi ini biasanya siswa bercerita tentang pengalaman pribadinya dan pengetahuan yang telah didapat sebelumnya yang berkaitan dengan materi, yang kemudian di tanggapi oleh guru.

3. Pengelompokan jam pelajaran untuk mata pelajaran Pendiidkan Agama Islam

Kemudian terdapat pula upaya dari sekolah dan guru yaitu pengelompokan jam pelajaran, yang disesuaikan dengan kemampuan dan kondisi peserta didik yaitu dengan mengelompokan siswa yang dianggap sudah besar yaitu kelas 5, 6 dalam satu jam pelajaran, dan siswa yang dianggap masih kecil yaitu kelas 2, 3, 4 dalam satu jam pelajaran. Pengelompokan jam pelajaran dilakukan, karena menurut guru dan kepala sekolah, kemampuan siswa untuk menangkap dan memahami materi yang sudah diajarkan cukup rendah yang di karenakan adanya gangguan emosi dan perilaku yang dimiliki siswa, sehingga perlu adanya pengulangan materi bagi siswa yang sebenarnya sudah mempelajari di kelas sebelumnya, dan juga disesuaikan dengan kondisi siswa. Serta disesuaikan dengan kondisi siswa, yang terkadang jika di jadikan satu dengan siswa yang tidak cocok maka dapat membuat keributan di kelas saat pelajaran.

\section{Reward dan Punishment}

Terkadang ada saat dimana kondisi siswa tidak sesuai dengan yang diharapkan oleh guru, seperti saat siswa mempunyai masalah sebelum masuk sekolah atau sebelum masuk kelas, yang dimana masalah tersebut belum terselesaikan dengan baik. Kondisi seperti ini dapat membuat siswa melakukan hal-hal yang tidak di inginkan, yang berdampak pada minat belajar siswa. Strategi yang guru lakukan agar dapat menumbuhkan lagi minat belajar siswa tersebut adalah dengan menawarkan reward seperti menonton film atau belajar di luar kelas, sehingga dapat dikatakan fokus strategi ini lebih kepada siswa yang bermasalah tersebut. Jika siswa dengan reward masih tetap bermasalah atau tidak mau mendengarkan atau mematuhi guru, maka guru akan memberi punishment 
kepada siswa dengan gertakan-gertakan secukupnya hanya untuk memberi efek jera kepada siswa yang bermasalah tersebut.

Hal tersebut dilakukan guru karena siswa yang bermasalah dapat mempengaruhi teman siswa yang tidak bermasalah dan dapat melakukan hal-hal yang tidak di inginkan. Sehingga dapat berpengaruh pada minat belajar siswa lainya, sehingga strategi yang digunakan untuk menumbuhkan minat belajar siswa adalah strategi yang disesuaikan dengan kondisi dan kemampuan siswa.

\section{Kerjasama dengan Guru Kelas}

Ketika melakukan observasi, terdapat satu siswa yang memiliki masalah sebelum masuk kelas yang kemudian masih terbawa atau belum terselesaikan saat setelah masuk kelas, setelah dibujuk beberapa kali oleh guru PAI namun siswa tersebut tidak kunjung terselesaikan masalahnya. Kemudian, guru PAI meminta bantuan kepada guru kelas yang bersangkutan untuk mencoba membujuk agar siswa mau mengikuti pelajaran. Strategi yang digunakan oleh guru PAI saat proses pembelajaran sebenarnya efektif untuk menentukan informasi atau membengun keterampilan tahap demi tahap, namun karena metode pembelajaran yang kurang variatif di setiap pertemuannya terkadang dapat membuat siswa kehilangan minatnya untuk belajar atau merasa bosan, yang kemudian mulai terjadi gejala-gejala yang menunjukan siswa mulai bosan seperti, siswa sudah tidak lagi konsentrasi dengan pelajaran yang diajarkan, siswa selalu ingin keluar kelas, siswa tidak menjawab pertanyaan yang diajukan guru, dan gejala lainnya.

\section{Penggunaan pendekatan untuk anak tunalaras}

Berdasarkan hasil dari penelitian, guru menggunakan beberapa pendekatan dalam startegi menumbuhkan minat belajar siswa tunalaras. Seperti model behavioral, dalam pendekatan model behavioral guru diharapkan dapat mengubah kebiasaan tersebut dengan modifikasi tingkahlaku kognitif. Modifikasi ini dapat dilakukan dengan penggunaan observasi, diskusi, dan pembelajaran. Kemudian dengan teori belajar sosial, yaitu dengan pemberian hadiah, hukuman, dan sebagainya. Dalam model ini guru diharapkan dapat mencapai tujuan pembelajaran yaitu siswa dapat menjadi lebih baik dari sebelumnya. Pendekatan 
behaviorial ini dapat terliaht dari tujuan dari pembelajaran di SLB E Prayuwana Yogyakarta bukanlah prestasi akademik melainkan diharapkan adanya perubahan perilaku pada siswa menuju ke yang lebih baik dari sebelumnya, karena yang menjadi perhatian utama sekolah dan guru adalah memperbaiki gangguan emosi dan perilaku yang dimiliki anak sehingga diharapakan dapat tumbuh minat belajar pada siswa.

Pelaksanaan model behavioral guru PAI tidak berkerja sendirian, melainkan berkerja sama dengan seluruh warga sekolah untuk selalu mengawasi dan memperhatikan segala perilaku dan kondisi anak. Diharapkan dengan adanya kerjasama ini siswa dapat selalu mendapat perhatian ketika melakukan hal-hal atau perilaku yang menyimpang, sehingga bisa langsung dapat di ingatkan dan di bimbing oleh para guru dan segenap warga sekolah, agar siswa bisa memperbaiki perilaku yang menyimpang sehingga tidak menjadi suatu kebiasaan yang buruk kedepannya yang dapat mengganggu tumbuhnya minat belajar siswa.

Kemudian pendekatan model psikodinamika. Dalam model ini guru di harapkan dapat membantu siswa untuk mengekspresikan dan mengendalikan perasaannya, sehingga diharapkan tumbuh minat untuk belajar ketika siswa dapat mengekspresikan dan mengendalikan perasaanya. Pelaksanaan model psikodinamika ini, guru berusaha membantu siswa mengekspresikan dan mengkonstruksi pengetahuan yang dimiliki oleh siswa lewat diskusi, tanya jawab, yang termasuk dalam strategi pembelajaran CTL. Sehingga diharapkan dengan pendekatan ini dapat tumbuh minat belajar pada siswa.

Kemudian model ekologis. Dalam model ini guru diharapkan dapat mengubah persepsi lingkungan terhadap anak atau anak terhadap lingkungan sehingga diharapkan dapat terjadi interaksi yang lebih baik antara anak dengan lingkungan. Pelaksanaan model ekologis ini yaitu dengan usaha kerjasama warga sekolah, baik guru, kepala sekolah, maupun karyawan sekolah, untuk membuat setting lingkungan yang nyaman bagi siswa, dan berusaha agar lingkungan sekitar siswa juga merasa nyaman dengan kehadiran siswa di lingkungan tersebut. Diharapkan setelah anak dapat berinteraksi dengan baik dengan lingkungannya, anak dapat diajak untuk belajar dan dapat tumbuh minat belajar pada anak. 
Sehingga dapat terecapainya tujuan belajar yang diharapkan, yaitu adanya perubahan perilaku siswa menjadi lebih baik dari sebelumnya.

\section{Faktor Penghambat Guru PAI Menumbuhkan Minat Belajar Siswa}

Ketika melaksanakan strategi guna menumbuhkan minat belajar pada siswa, pastinya guru menemukan hambatan khususnya pada siswa tunalaras. Siswa yang memiliki gangguan perilaku dan emosi tentu memiliki karakteristik yang berbeda dalam penanganan nya dengan siswa normal yang tidak memiliki gangguan apapun. Berdasarkan pada faktor yang dapat mempengaruhi minat belajar siswa, dan faktor-faktor penyebab rendahnya minat belajar siswa, yang kemudian di gabungkan dengan hasil penelitian di SLB E Prayuwana Yogyakarta, terdapat beberapa faktor-faktor pengambat dalam pelaksanaan strategi, sehingga guru mengalami kesulitan dalam berupaya untuk melaksanakan strategi pembelajaran untuk menumbuhkan minat belajar siswa. Faktor penghambat dalam penelitian ini dibagi menjadi 3 yaitu faktor internal, faktor eksternal dan faktor pendekatan.

Faktor internal yang menghambat guru PAI dalam menumbuhkan minat belajar siswa adalah adanya gangguan fisik atau kesehatan pada siswa. Siswa yang bersekolah di SLB E Prayuwana Yogyakarta adalah anak yang memiliki kelainan gangguan perilaku dan emosi. Dimana siswa sulit untuk mengendalikan emosinya dan dapat melakukan hal-hal yang tak seharusnya dilakukan. Hal tersebutlah yang menjadi tantangan bagi guru untuk menerapka strategi pembelajaran yang dapat menumbuhkan minat belajar siswa tunalaras, agar tujuan pembelajaran dapat tercapai. Berdasarkan hasil wawancara dengan guru PAI faktor penyebab tunalaras siswa di SLB E Prayuwana Yogyakarta mayoritas adalah berasal dari lingkungan keluarga. Hal ini juga di perkuat dengan pernyataan dari kepala sekolah SLB E Prayuwana Yogyakarta yang juga mengatakan bahwa mayoritas penyebab ketunalarasan siswa di SLB E Prayuwana Yogyakarta adalah adanya masalah pada keluarga atau disebut broken home, seperti orang tua yang sudah cerai, konflik internal keluarga, orangtua yang sudah meninggal. Sehingga terkadang anak melihat atau bahkan terlibat dalam masalah atau konflik tersebut, yang kemudian terekam dalam memori ingatannya dan 
mencontoh perilaku yang seharusnya tidak dicontoh yang bersumber dari masalah atau konflik yang ada. Hal tersebut menyebabkan guru merasa kesulitan dalam mengimplementasikan strategi guna menumbuhkan minat belajar siswa tunalaras.

Hambatan lainnya adalah kurangnya motivasi belajar pada siswa, karena belum menyadari pentingnya belajar untuk masa depan. Berdasar hasil penelitian yang ada, sebenarnya siswa sudah memiliki motivasi untuk belajar karena siswa sadar bahwa untuk naik kelas dan lulus dari sekolah dibutuhkan nilai yang baik. Akan tetapi tidak ada usaha lebih dari siswa untuk mendapatkan nilai yang baik, siswa hanya berkata pada guru untuk meminta nilai baik. Kemungkinan hal ini terjadi dapat dikarenakan gangguan emosi dan perilaku yang dimiliki siswa, sehingga siswa sulit untuk berusaha lebih agar bisa mengusai materi yang diajarkan dan berhsail mendapat nilai yang baik, yang menjadi salah satu faktor penghambat. Karena memang sesunggunhnya tujuan pembelajaran di SLB E Prayuwana Yogyakarta ini bukanlah nilai akademis akan tetapi perbaikan perilaku siswa tunalaras. Salah satunya adalah lingkungan keluarga siswa.

Hambatan selanjutnya adalah hambatan yang berasal dari faktor eksternal. Keluarga siswa menjadi faktor penting yang dapat menumbuhkan minat belajar siswa. Keluarga yang kurang memperhatikan pendidikan anaknya menyebabkan anak menjadi kurang berminat untuk belajar di sekolah, sehingga anak sering tidak masuk sekolah tanpa alasan yang jelas, dan ketika di sekolah anak tidak terlalu mementingkan apa yang sedang diajarkan oleh gurunya, karena tidak adanya dorongan atau perhatian dari keluarga (Yumnah, 2021). Selain itu, lingkungan tempat belajar siswa juga menjadi salah satu penghambat dalam menumbuhkan minat belajar siswa di SLB E Prayuwana. kondisi lingkungan tempat belajar siswa seperti kelas yang kurang berwarna walaupun sudah cukup baik kondisinya, akan tetapi hal ini perlu diperhatikan sebagai salah satu upaya untuk membuat siswa nyaman di kelas yang kemudian berpengaruh pada minat belajar siswa. Kemudian, saat ada siswa lain yang mengalami masalah saat proses pembelajaran, yang kemudian mengganggu siswa yang sedang belajar. Hal ini dapat mengganggu proses pembelajaran, dan mempengaruhi siswa minat belajar siswa yang lain. 
Jam pelajaran yang dijadikan satu dengan kelas-kelas lain menyebabkan dalam satu kelas terdapat beragam karakteristik dan kemampuan siswa, seperti contohnya dalam satu jam pelajaran ada siswa dengan berbagai macam gangguan, seperti tunalaras murni jadi satu dengan yang campuran tunalaras dan tunagrahita, dan juga jadi satu dengan yang tunagrahita murni. Sehingga guru terkadang kewalahan dengan karakteristik siswa yang berbeda-beda dalam satu kelas.

Hambatan yang terakhir yaitu berdasarkan faktor pendekatan. Kesulitan dalam menghadapi karakteristik siswa yang berbeda-beda menjadi salah satu hambatan dalam mengimplementasikan strategi guna menumbuhkan minat belajar pada siswa. Setiap kelas pasti memiliki karakteristik siswa yang berbedabeda, dengan latar belakang yang berbeda juga. Seperti sesaat sebelum masuk kelas atau sekolah, siswa membawa suatu masalah yang belum terselesaikan sehingga membuat anak jadi bersifat sensitif dan tempramen. Sehingga guru harus mengetahui kondisi tiap siswa sebelum memulai pelajaran, sehingga guru dapat menganalisis strategi mana yang tepat untuk digunakan saat itu. Hambatan lainnya adalah sulitnya menentukan materi yang cocok untuk kejiwaan dan jenjang peserta didik dan sulitnya menentukan metode yang sesuai agar siswa tidak bosan. salah satu perhatian berdasarkan hasil penelitian yang ada bahwa, guru masih menggunakan metode pembelajaran yang itu-itu saja, walaupun sudah menggunakan strategi yang baik, akan tetapi jika guru kurang variatif dalam penggunaan metode pembelajaran dapat berdampak pada menurunnya minat belajar siswa karena siswa merasa bosan. Sehingga dslam hal ini diperlukan kompetensi guru dalam menentukan metode yang bermacam-macam sehingga dapat menumbuhkan minat belajar siswa.

\section{Solusi Bagi Guru PAI untuk Menumbuhkan Minat Belajar Siswa Tunalaras di SLB E Prayuwana Yogyakarta}

Guna mengatasi dan melewati hambatan yang ada untuk menumbuhkan minat belajar siswa tunalaras di SLB E Prayuwana Yogyakarta perlu adanya solusisolusi yang diharapkan dapat menyelesaikan dan memperbaiki keurangan yang ada. Agar dapat tercepainya tujuan pembelajaran yang diharapkan dan disepakati 
oleh semua pihak. Solusi yang pertama adalah peningkatan pengetahuan tentang kondisi dan kemampuan siswa. Adanya hubungan antara sekolah dan keluarga siswa yang lebih intensif untuk lebih mengatahui kondisi dan kemampuan anak secara teratur, sehingga guru dapat menentukan dan menyusun strategi yang tepat dengan kondisi dan kemampuan anak.

Hal ini dapat dilakukan melalui acara pertemuan antara guru dan wali murid yang sebenarnya memang sudah di upayakan, namun diluar itu guru juga dapat berkomunikasi dengan orangtua atau wali siswa, yaitu dengan selalu memberikan kabar tentang siswa ketika bertemu disekolah saat orang tua mengantar atau menjemput anaknya, kemudian saat siswa tidak masuk sekolah guru menanyakan penyebabnya pada orangtua/ wali, sehingga adanya kedekatan antara guru dan orangtua/ wali untuk saling berbagi informasi tentang siswa sehingga guru dapat memahami siswa secara menyeluruh dan mendalam. Diharapkan setelah guru memahami siswa secara baik, guru dapat mengetahui apa kebutuhan dan keinginan siswa, sehingga jika kebutuhan dan keinginan siswa dapat terpenuhi dengan baik diharapkan tidak ada hambatan untuk melaksanakan strategi pembelajaran untuk menumbuhkan minat belajar siswa.

Solusi yang kedua adalah adanaya perubahan lingkungan belajar menjadi lebih baik. Lingkungan merupakan faktor eksternal yang dapat mempengaruhi mnat belajar siswa. Sehingga menjadi sangat penting, karena strategi utama guru untuk menumbuhkan minat belajar siswa yaitu dengan membuat nyaman siswa, dan jika lingkungan belajar mendukung untuk membuat siswa nyaman maka minat belajar siswa akan bertambah. Upaya yang dapat dilakukan yaitu dengan pengubahan setting kelas, seperti warna tembok kelas yang lebih berwarna, tata letak barang di kelas, kemudian penambahan aksesoris-aksesoris yang membuat siswa merasa nyaman di kelas, kebersihan kelas, dan lain sebagainya.

Solusi ketiga adalah pengelompokan jam belajar yang lebih disesuaikan. Salah satu kendala yang dihadapi guru PAI saat mengajar adalah susahnya mengkodisikan kelas yang di dalamnya terdapat siswa dengan berbagai macam gangguan, sehingga sebaiknya siswa dikelompokkan sesuai dengan gangguan yang dimiliki siswa sehingga guru lebih dapat mudah dalam mengandalikan siswa 
di dalam kelas. Selain itu, pengembangan dan peningkatan kompetensi dan kemampuan guru PAI juga penting. Siswa tunalaras dengan siswa biasa yang tidak memiliki gangguan apapun tentu memiliki karakteristik yang sangat berbeda, sehingga butuh keahlian dan kemampuan yang khusus untuk anak dengan gangguan tunalaras. Sehingga guru perlu meningkatkan kemampuan dan kompetensi agar bisa memahami kebutuhan dan strategi yang tepat untuk anak dengan gangguan tunalaras.

Berdasarkan hasil penelitian yang ada, sebenarnya guru sudah dimiliki kemampuan yang memumpuni untuk mengajar di SLB E Prayuwana Yogyakarta, guru yang bersangkutan juga terus berkerjasama dengan guru lain dan kepala sekolah untuk menangani masalah-masalah yang ada. Namun, akan lebih baik jika kemampuan tersebut terus ditingkaktan ketingkat yang lebih spesifik, seperti melalui pelatihan-pelatihan, studi banding, dan hal-hal lain yang dianggap dapat meningkatkan kemampuan dan kompetensi guru, karena dilihat dari riwayat pendidikan dan profesi guru PAI saat ini belum memenuhi standar kompetensi guru untuk pendidikan khusus walaupun kemampuannya sudah memumpuni. Hal ini menjadi sangat penting karena, dengan adanya kompetensi dan kualifikasi guru yang semakin meningkat diharapkan dapat lebih memahami konsisi siswa dan apa yang dibutuhkan siswa (Syam, 2017).

Solusi yang terakhir adalah dengan menambah variasi strategi pembelajaran. Perlu adanya variasi pelaksanaan strategi pembelajaran dari guru agar siswa tidak jenuh. Variasi strategi pembelajaran tersebut seperti reading guide, student question have yaitu untuk mengetahui keinginan dan harapan siswa, the power of two yaitu belajar secara berpasangan bukan secara individual sehingga diharapkan murid dapat berkerjasama dengan teman lainya di dalam kelas. 


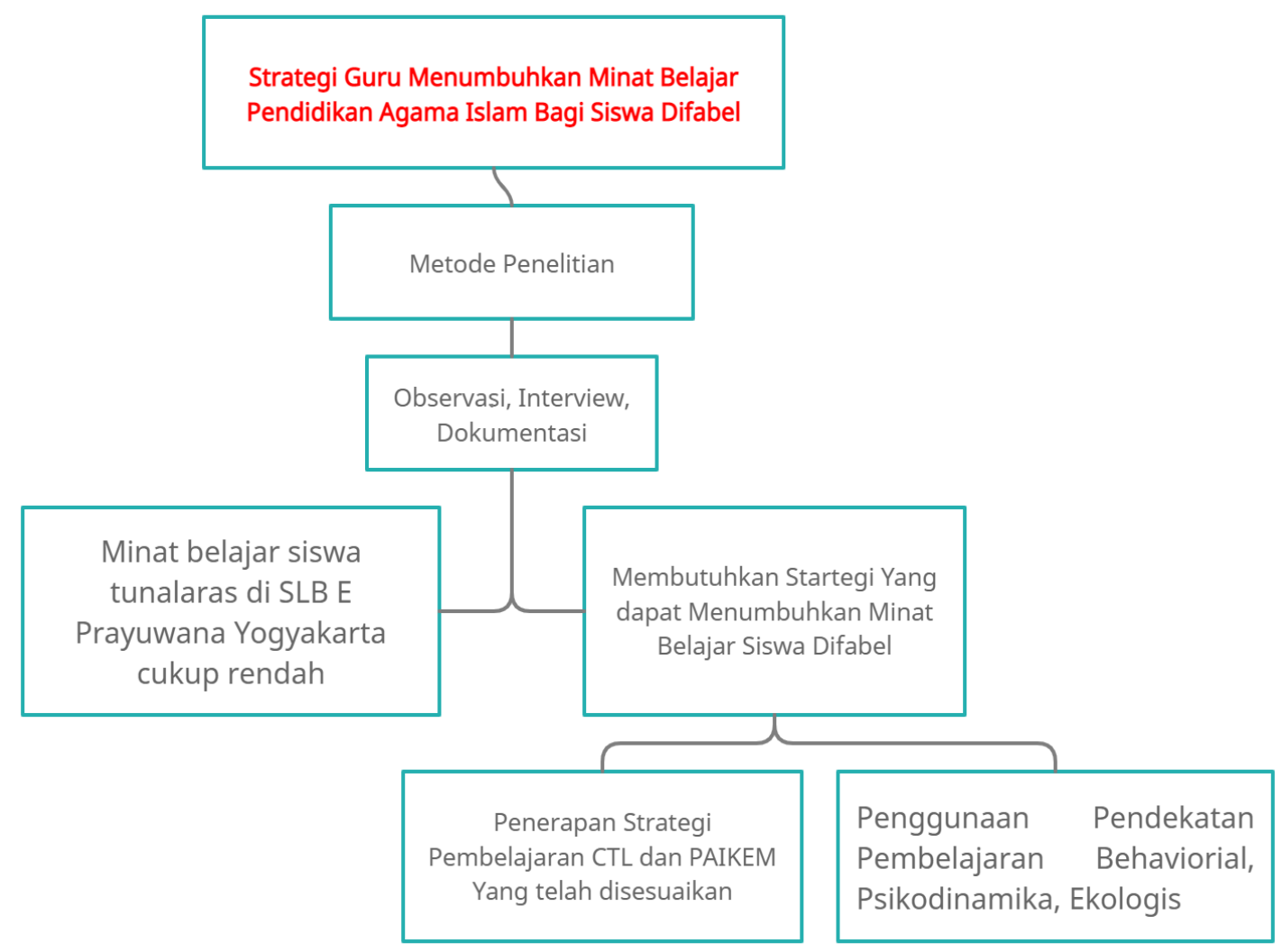

Gambar 1. Diagram penerapan srategi pembelajaran dalam menumbuhkan minat belajar siswa

\section{KESIMPULAN}

Berdasarkan hasil dan pembahasan dapat disimpulkan bahwa minat belajar siswa tunaaras di SLB E Prayuwana Yogyakarta masih cukup rendahsehingga diperlukan strategi guna menumbuhkan minat belajar siswa. Guru PAI di SLB E Prayuwana Yogyakarta menerapkan strategi CTL dan PIKEM sebagai salah satu strategi dalam menumbuhkan minat belajar siswanya. Terdapat beberapa faktor penghambat dalam pengimplementasian strategi sehingga guru mengalami kesulitan dalam berupaya untuk melaksanakan strategi pembelajaran untuk menumbuhkan minat belajar siswa. Faktor penghambat tersebut antara lain yaitu terdapatnya gangguan fisik dan kesehatan pada siswa, kurangnya motivasi belajar pada siswa, karena belum menyadari pentingnya belajar untuk masa depan, lingkungan keluarga siswa, pengeompkan pelajaran yang kurang sesuai, lingkungan teman pergaulan siswa, lingkungan tempat belajar siswa, kesulitan dalam menghadapi siswa yang memiliki karakteristik berbeda-beda, kesulitan menentukan materi yang cocok untuk kejiwaan dan jenjang peserta didik serta 
kesulitan untuk mennetukan berbagai metode yang sesuai agar siswa tidak bosan. Saran yang dapat peneliti berikan kepada guru PAI di SLB E Prayuwana Yogyakarta yaitu sekolah sebaiknya memfasilitasi pembaharuan sarana dan prasarana penunjang pembelajaran, pihak sekolah sebaiknya mengupayakan dan memotivasi guru yang belum memiliki sertifikat profesi agar bisa mendapatkan sertifikat profesi sehingga tujuan sekolah dapat tercapai.

\section{BIBLIOGRAFI}

[1] Amidah. (2014). Strategi Guru Dalam Meningkatkan Minat Belajar Siswa Pada Mata Pelajaran Pendidikan Agama Islam Di Sekolah Dasar Negeri 147 Palembang. Darul IImi: Jurnal IImu Kependidikan Dan Keislaman, 72), 215226. https://doi.org/10.24952/di.v7i2.2241

[2] Anwar, A. W. (2018). Penerapan Metode Pembelajaran Pendidikan Agama Islam Pada Anak Tunalaras Tingkat SD Kelas V di SLB Bhina Putera Surakarta Tahun Ajaran 2017/2018. IAIN Surakarta.

[3] Anwar, S. (2021). Pendidikan Karakter: Kajian Perspektif Tafsir fi Zilalil Qur'an. Tulungagung: STAI Muhammadiyah Tulungagung.

[4] Enggan, P., \& Kauchak, D. (2012). Stategi dan Model Pembelajaran. Jakarta: PT Indeks Kelompok Gramedia.

[5] Husna, D. (2020). Internalisasi Nilai-Nilai Sosial Religius Bagi Anak Tunalaras di SLB E Prayuwana Yogyakarta. Jurnal Tarbiyatuna, 11(1), 1-10. https://doi.org/10.31603/tarbiyatuna.v11i1.3044

[6] Ikhwan, A. (2019). Public Relations in an Islamic Perspective; Implementation Study at Madrasah. At-Turats: Jurnal Pemikiran Pendidikan Islam, 13(2), 105-117.

[7] Ikhwan, A. (2021). Metode Penelitian Dasar (Mengenal Model Penelitian dan Sistematikanya). Tulungagung: STAI Muhammadiyah Tulungagung.

[8] Khairani, M. (2017). Psikologi Belajar. Yogyakarta: Aswaja.

[9] Maftuhin, M., \& Fuad, A. J. (2018). Pembelajaran Pendidikan Agama Islam Pada Anak Berkebutuhan Khusus. Journal An-Nafs: Kajian Penelitian Psikologi, 3(1), 76-90. https://doi.org/10.33367/psi.v3i1.502

[10] Mahfida, U. U. (2017). Pendidikan Agama Islam pada Anak Tunalaras di SLB E Prayuwana Yogyakarta. UIN Sunan Kalijaga Yogyakarta.

[11] Oktari, W., Harmi, H., \& Wanto, D. (2020). Strategi Guru Dalam Pembelajaran Pai Pada Anak Berkebutuhan Khusus. TA'DIBUNA: Jurnal Pendidikan Agama Islam, 3(1), 13. https://doi.org/10.30659/jpai.3.1.13-28

[12] Rahmanto, A. (2017). Strategi Pembelajaran dalam Menumbuhkan Minat Belajar PAI Bagi Siswa Difabel Tunalaras. Jurnal Sunan Kalijaga, 3(3). 
[13] Rusmiati. (2017). Pengaruh minat belajar terhadap prestasi belajar bidang studi ekonomi siswa MA Al Fattah Sumbermulyo. Jurnal Ilmiah Pendidikan Dan Ekonomi, 1(1), 21-36.

[14] Setiawan, A. (2009). Mengembangkan Motivasi Belajar pada Anak Tunalaras. Jassi Anakku, 8(1), 54-60.

[15] Syah, M. (2011). Psikologi Belajar. Jakarta: Raja Grafindo.

[16] Syam, A. R. (2017). Urgensi Budaya Organisasi Untuk Pengembangan Lembaga Pendidikan Islam. Educan: Jurnal Pendidikan Islam, 1(2).

[17] Yumnah, S. (2021). The Learning Model of Islamic Education in Al-Ihsan Integrated Islamic Basic Schools (SDIT) Pasuruan. JIE: Journal of Islamic Edication, 6(1). 